\title{
HUBUNGAN ANTARA LAMA PEMAKAIAN ALAT KONTRASEPSI KB SUNTIK 3 BULAN DENGAN GANGGUAN MENSTRUASI PADA AKSEPTOR KB DI PUSKESMAS SIANTAN HILIR PADA TAHUN 2019
}

\author{
Alexander ${ }^{1}$, Melyani $^{2}$ \\ Akademi Kebidanan Panca Bhakti Pontianak \\ Email korespondensi: akbidpbpontianak@gmail.com
}

\begin{abstract}
Abstrak
Kontrasepsi suntik mempunyai permasalahan utama efek samping Pemakaian KB suntik mengalami beberapa permasalahan utama, yaitu gangguan pola menstruasi. Gangguan menstruasi yang terjadi seperti perdarahan bercak, perdarahan irregular, amenorea dan perubahan dalam frekuensi, lama dan jumlah darah yang hilang. Tujuan penelitian ini untuk mengetahui Hubungan Lama Pemakaian Alat Kontrasepsi Suntik 3 Bulan Dengan Ganggua Menstruasi Pada Akseptor KB di Puskesmas Siantan Hilir Pada Tahun 2019. Penelitian ini merupakan jenis penelitian Deskriftif korelasi yang digunakan untuk mengetahui tingkat hubungan antara dua variabel atau lebih. Populasi dari penelitian ini adalah seluruh ibu yang melakukan kunjungan KB suntik bulan Mei Tahun 2019 yang berjumlah 34 orang dengan menggunakan total sampling. Hasil univariat di dapatkan hasil data dari 34 responden yaitu 24 orang $(70,5 \%)$ sudah mengguanakan KB suntik 3 bulan selama $\geq 1$ tahun serta mengalami gangguan menstruasi dan 10 orang $(29,5 \%)$ menggunakan $\mathrm{KB}<1$ tahun dan tidak mengalami gangguan menstruasi. Sedangkan hasil bivariat dilihat dari uji staristik chi squere di dapatkan hasil $\mathrm{x}^{2}$ hitung lebih besar dari $\mathrm{x}^{2}$ tabel yaitu $\mathrm{x}^{2}$ hitung $=8,503>\mathrm{x}^{2}$ tabel $=3,841$ maka dapat di simpulkan bahwa $\mathrm{H}_{\mathrm{a}}$ diterima dan $\mathrm{H}_{\mathrm{O}}$ ditolak. Kesimpulan penelitian ini yaitu ada Hubungan Lama Pemakain Alat Kontasepsi KB Suntik 3 Bulan Dengan Gangguan Menstruasi Pada Akseptor KB di Puskesmas Siantan Hilir Pada Tahun 2019. Bagi Puskesmas Siantan Hilir Pihak Puskesmas tetap dilakukan informasi pada pengguna KB suntik 3 bulan terutama tentang efek samping pemakaian KB suntik 3 bulan, serta menjelaskan pada klien bahwa ada hubungan antara lama pemakaian KB suntik 3 bulan dengan gangguan menstruasi, dan menganjurkan klien jika merasa ada gangguan terhadap pemakaian KB suntik 3 bulan untuk mengganti metode kontrasepsi lainnya.
\end{abstract}

Kata Kunci: Lama Pemakaian, Suntik 3 Bulan, Gangguan Menstruasi

\section{Pendahuluan}

$$
\text { Kontrasepsi suntik adalah alat }
$$

kontrasepsi berupa cairan yang berisi hormon progesteron yang disuntik kedalam tubuh wanita secara periodik (1 bulan sekali atau 3 bulan sekali). Keuntungan menggunakan KB suntik adalah praktis, efektif dan aman dengan tingkat keberhasilan lebih dari 99\% (Irianto, 2014).

Lamanya penggunaan kontrasepsi suntik pada akseptor KB suntik rata-rata memiliki keberhasilan di atas 99\%. Keuntungan menggunakan $\mathrm{KB}$ suntik adalah praktis, efektif dan aman. Tidak membatasi usia dan obat KB

\footnotetext{
${ }^{1}$ Dosen Akademi Kebidanan Panca Bhakti Pontianak

${ }^{2}$ Dosen Akademi Kebidanan Panca Bhakti Pontianak
}

suntik 3 bulan sekalipun tidak mempengaruhi asi dan cocok untuk ibu yang menyusui (Irianto, 2010).

Lama pemakaian $\mathrm{KB}$ suntik 3 bulan dapat menyebabkan gangguan menstruasi menurut penelitan Riyanti (2011) hasil menunjukan bahwa lama pemakian KB suntik 3 bulan berhubungan signifikan dimana semakin lama penggunaan KB suntik 3 bulan maka kejadian lama menstruasi akseptor KB suntik 3 bulan semakin memendek bahkan sampai menjadi tidak menstruasi perubahan lama menstruasi tersebut di sebabkan 
komponen gestagen yang terkandung di dalam

DMPA. Perubahan ini sejalan dengan kekurangan darah menstruasi pada akseptor KB suntik 3 bulan. Setelah penggunaan jangka lama jumlah darah haid semakin sedikit dan bisa terjadi amenorea (Riyanti, 2011).

Umumnya pemakaian $\mathrm{KB}$ suntik 3 mempunyai persyaratan yang sama dengan pil, penggunaan cara $\mathrm{KB}$ hormonal maksimal selama 5 tahun, semakin lama masa pemaiakan KB suntik akan menimbulkan beberapa dampak baik mual muntah, perdarahan libido, pengeroposan tulang dan lainya (Harnawati, 2008).

\section{Menurut World Health Orpganization} (WHO 2014) Penggunaan kontrasepsi telah meningkat di banyak bagian dunia, di perkirakan 225 juta perempuan di negaranegara berkembang ingin menunda atau menghentikan kesuburan tapi tidak menggunakan metode kontrasepsi apapun dengan alasan sebagai berikut, terbatas memilih alat kontrasepsi dan penggalaman efek samping. Kebutuhan yang belum terpenuhi untuk kontrasepsi masih terlalu tinggi. Ketidak adilan didorong oleh pertumbuhan populasi (WHO, 2014).

Indonesia merupakan sebuah negara berkembang dengan jumlah penduduk sebesar 252.124.458 jiwa dengan luas wilayah 1.931.378,68 km dan kepadatan penduduk sebesar 131,76 jiwa/km (Depkes RI, 2014). Di Indonesia kontrasepsi suntik menempati urutan pertama, dalam penggunaan kontrasepsi suntik petugas kesehatan harus menjelaskan efektifitas, keuntungan, kerugian, indikasi dan kontraindikasi pada calon akseptor KB suntik. Efektifias kontrasepsi suntik adalah (99\% dan100\%) dalam mencegah kehamilan. Walaupun mempunyai efektifitas tinggi dan pelaksanaannya mudah, kontrasepsi suntik mempunyai efek samping terutama mengganggu siklus haid. Kenaikan berat badan juga merupakan salah satu efek samping yang sering dikeluhkan oleh akseptor KB suntik, Beberapa wanita juga mengeluh timbulnya jerawat di wajah (Susanti, 2013).

Kontrasepsi suntik 3 bulan (progestin) jenis kontrasepsi ini sangat efektif, aman, dapat di pakai oleh semua perempuan dalam usia reproduksi, kembalinya kesuburan lebih lambat kira - kira 4 bulan, tidak menekan produksi ASI sehingga cocok untuk masa laktasi. Efektivitas suntikan progestin baik DMPA maupun NET EN memiliki efektivitas yang tinggi dengan 0,3 kehamilan per 100 perempuan per tahun asal penyuntikan dilakukan secara benar sesuai dengan jadwal yang telah di tentukan (Pinem, 2009).

Efek samping dari KB suntik 3 bulan adalah gangguan haid,berat badan yang bertambah antara 1-5 kg. Sakit kepala, tetapi perubahan- perubahan tersebut akan menjadi normal dalam waktu 90 hari setelah suntik KB progestin yng terakhir (Hartano, 2010). Setelah penghentian suntikannya dan kontinuitas kontrasepsi suntik cukup tinggi, 50-75\% setelah 1 tahun (hartanto,2010) akan mengalami Amenorea, spoting, metroraghia, dan menoragia (Suratun, 2008).

Efek samping ini di pandang sebagai kekurangan oleh banyak wanita dan menganggap bahwa pendarahan teratur 
merupakan suatu tanda kesehatan dan menggunakan haid sebagai indikator bahwa mereka tidak hamil. Penyebab gangguan haid karena adanya ketidak seimbangan hormon sehingga endometrium mengalami perubahan histology. Keadaan amenorea disebabkan atropi endometrium. Pemberian DMPA yang semakin lama atau rutin setiap 3 bulannya akan mempengaruhi estrogen di dalam tubuh kurang kuat terhadap endometrium, sehingga endometrium kurang sempurna (Irianto, 2014).

Berdasarkan jurnal kesehatan Samodra ilmu (2017), penggunaan kontrasepsi suntik progestin menurut Siswosudomo (2017) menyebabkan ketidak seimbangan hormon, dengan penggunaan suntik hormonal tersebut membuat dinding endometrium yang semakin menipis hingga menimbulkan bercak perdarahan. Efek pada pola haid tergantung pada lama pemakain, pendarahan inter menstruasi dan perdarahan bercak berkurang dengan berjalannya waktu. Dan kasus amenorea semakin banyak dengan lama pemakain kontrasepsi suntik 3 bulan.

Pada tahun 2017 jumlah pasangan usia subur (pus) Kalimantan Barat sebesar 859.660 yang memiliki alat kontasepsi jenis suntik sebesar 287.485 (57,9\%) (Dinkes, 2017). Berdasarkan data yang di peroleh oleh peneliti dari Puskesmas Siantan Hilir Pada tahun 2018. Metode Keluarga berencana yang paling diminati akseptor KB ialah KB Suntik 3 Bulan. Hasil rekapan kunjungan bulanan akseptor KB suntik 3 Bulan Pada bulan Januari-Desember 2018 dengan jumlah total cakupan wilayah Puskesmas Siantan Hilir
95,1\% akseptor, kemudian KB suntik 1 bulan yaitu $80 \%$ akseptor, Pil $75 \%$ akseptor, Kondom 49,3\% aksetor, IUD 81\% akseptor, Implant $65 \%$ akseptor. ari hasil rekapan kunjungan akseptor KB suntik 3 bulan pada tahun 2018 dapat di simpulan bahwa kunjungan KB suntik 3 bulan paling banyak ditemukan setiap bulan nya dengan total kunjungan periode Januari 2018 Sampai dengan Desember 2018 sebanyak 15.818 $(95,1 \%)$ akseptor dengan kunjungan \pm 1000 1400 setiap bulannya.

Dari hasil wawancara kepada 5 responden Akseptor KB suntik 3 bulan didapatkan data 4 orang akseptor mengalami amenorea setelah suntik KB 3 bulan lebih dari 1 tahun, dan 1 orang akseptor KB suntik 3 bulan tidak mengalami gangguan haid setelah melakukan suntik $\leq 1$ tahun. Berdasarkan pengamatan yang dilakukan peneliti memperoleh bahwa dalam menggunakan alat kontrasepsi suntik 3 bulan mempunyai efek samping atau resiko terjadi gangguan haid, Hal ini terjadi karena saat menggunakan alat kontasepsi suntik yang mengandung hormon estrogen maupun progesteron dapat mencegah ovulasi, sedangkan siklus menstruasi biasanya normal karena terjadi reaksi antara hipotalamus, hipofisis, dan ovarium serta organ reproduksi yang sehat ini kemudian terjadi ketidak seimbangan hormon yang di akibatkan dari pemakaian alat kontrasepsi tersebut sehingga dapat memberikan efek kontrasepsi seperti yang dilakukan oleh sebagian responden tersebut.

Berdasarkan data yang peneliti peroleh dimana metode kontrasepsi suntik 3 bulan 
yang paling banyak digunakan di Puskesmas

Siantan Hilir dan ada akseptor yang mengalami efek sampingnya yaitu berupa gangguan menstruasi dan tidak mengalami efek sampingnya berdasarkan dari lama pemakaian KB suntik 3 bulan. Sehingga peneliti tertarik untuk melakukan penelitian tentang Hubungan Lama Pemakaian Alat Kontasepsi Suntik 3 Bulan Dengan Gangguan Menstruasi Pada Akseptor KB di Puskesmas Siantan Hilir Pada Tahun 2019.

\section{Metode}

Pada penelitian ini menggunakan metode deskriptif korelasi dengan pendekatan secara cross sectional. Sampel dalam penelitian ini sebanyak 34 akseptor kb suntik 3 bulan. Pengumpulan data menggunakan kuesioner dan observasi, kemudian diolah dan dianalisis menggunakan analisis univariat serta analisis bivariat menggunakan uji chi square.

\section{Hasil dan Pembahasan}

Tabel 1. Distribusi Responden Berdasarkan Lamanya Pemakaian Alat Kontrasepsi Suntikan di Puskesmas Siantan Hilir

\begin{tabular}{ccc}
\hline Lamanya Pemakaian KB Suntik & N & $\%$ \\
\hline$\geq 1$ Tahun & 24 & 70,5 \\
$<1$ Tahun & 10 & 29,5 \\
\hline
\end{tabular}

Sebagian besar responden sebanyak 24 orang (70,5\%) sudah menggunakan KB Suntik 3 bulan lamanya $\geq 1$ Tahun dan sebagian kecil dari responden sebanyak 10 orang $(29,5 \%)$ menggunakan KB Suntik 3 bulan $<1$ tahun.

Tabel 2. Distribusi Responden yang Mengalami Gangguan Menstruasi di Puskesmas Siantan Hilir

\begin{tabular}{ccc}
\hline $\begin{array}{c}\text { Akseptor KB 3 bulan yang mengalami Gangguan } \\
\text { Menstruasi }\end{array}$ & $\mathrm{N}$ & $\%$ \\
\hline Ya & 24 & 70,5 \\
Tidak & 10 & 29,5 \\
\hline
\end{tabular}

Sebagaian besar responden sebanyak 24 orang (70,5\%) mengalami Gangguan menstruasi dan Sebagian kecil dari Responden 10 orang
$(29,5 \%)$ Tidak mengalami Gangguan Menstruasi.

Tabel 3. Distribusi Responden yang Mengalami Gangguan Menstruasi berdasarkan Jenis gangguannya di Puskesmas Siantan Hilir Tahun 2019

\begin{tabular}{ccc}
\hline $\begin{array}{c}\text { Akseptor KB } 3 \text { bulan yang Mengalami Gangguan } \\
\text { Menstruasi Berdasarkan Jenisnya }\end{array}$ & $\mathrm{N}$ & $\%$ \\
\hline Amenorea & 22 & 64,7 \\
Spooting & 1 & 2,9 \\
Menoraghia & 1 & 2,9 \\
\hline
\end{tabular}


Sebagian besar responden sebanyak 24 orang (70,5\%) mengalami Haid seperti Amenorea (tidak terjadi perdarahan) Sebanyak 22, spooting (Bercak-bercak) sebanyak 1 responden, dan menoragia (perdarahan banyak) sebanyak 1 orang responden.

Tabel 4. Hubungan Lama Pemakaian Alat Kontrasepsi KB Suntik 3 Bulan Dengan Gangguan Menstruasi Pada Akseptor KB di Puskesmas Siantan Hilir Pada Tahun 2019

\begin{tabular}{|c|c|c|c|c|c|c|c|}
\hline \multirow{3}{*}{$\begin{array}{c}\text { Lama Penggunaan KB } \\
\text { Suntik }\end{array}$} & \multicolumn{4}{|c|}{ Gangguan Menstruasi } & \multirow{3}{*}{ Total } & \multirow{3}{*}{$\begin{array}{l}\mathrm{P} . \\
\text { Value }\end{array}$} & \multirow{3}{*}{$\alpha$} \\
\hline & \multicolumn{2}{|c|}{ Ya } & \multicolumn{2}{|c|}{ Tidak } & & & \\
\hline & $\sum$ & $\%$ & $\sum$ & $\%$ & & & \\
\hline$\geq 1$ Tahun & 22 & 64,7 & 2 & 5,8 & 24 & & \\
\hline$<1$ Tahun & 2 & 5,8 & 8 & 23,7 & 10 & 0,600 & 0,05 \\
\hline
\end{tabular}

Lama pemakaian alat kontasepsi KB suntik 3 bulan dengan gangguan menstruasi pada akseptor kb dari 34 responden, sebagai besar responden sebanyak 22 orang $(64,7 \%)$ mengalami gangguan menstruasi lamanya pemakaian KB suntik $\geq 1$ tahun dan sebanyak 2 orang $(5,8 \%)$ akseptor KB dengan lama pemakaian $<1$ tahun mengalami gangguan menstruasi. Analisa data diperoleh $X^{2}$ hitung $(8,503)>X^{2}$ tabel $(3,841)$ maka Ha diterima dan Ho di tolak artinya Ada Hubungan Lama Pemakaian Alat Kontrasepsi KB Suntik 3 Bulan Dengan Gangguan Menstruasi Pada Akseptor KB.

\section{Lama Pemakaian Alat Kontrasepsi KB Suntik 3 Bulan}

Menurut Irianto (2010) Lamanya penggunaan kontrasepsi suntik pada akseptor KB suntik rata-rata memiliki keberhasilan di atas 99\%. Keuntungan menggunakan KB suntik adalah praktis, efektif dan aman. Tidak membatasi usia dan obat KB suntik 3 bulan sekalipun tidak mempengaruhi ASI dan cocok untuk ibu yang menyusui.
Umumnya pemakaian KB suntik 3 bulan mempunyai persyaratan yang sama dengan pil,kontinuitas kontrasepsi suntik cukup tinggi, $50-75 \%$ setelah 1 tahun, penggunaan cara KB hormonal maksimal selama 5 tahun, semakin lama masa pemaiakan KB suntik akan menimbulkan beberapa dampak baik mual muntah, perdarahan libido, pengeroposan tulang dan lainya (Harnawati, 2008).

Efek samping dari KB suntik 3 bulan adalah gangguan haid, berat badan yang bertambah antara 1-5 kg. Sakit kepala, Tetapi perubahan- perubahan tersebut akan menjadi normal dalam waktu 90 hari setelah suntik KB progestin yang terakhir (Hartano, 2010). Setelah penghentian suntikannya dan kontinuitas kontrasepsi suntik cukup tinggi, 50-75\% setelah 1 tahun (hartanto,2010) akan mengalami Amenorea, spoting, metroraghia, dan menoragia (Suratun, 2008).

Penelitian ini sejalan dengan penelitian yang di lakukan oleh Susanti, dkk tentang hubungan lama pengunaan suntik 3 bulan dengan kejadian amenorea di BPS Sami Manang Sukohardjo Tahun 2013 dari 30 responden yang menggunakan kontrasepsi 
suntik 3 bulan lebih dari 1 tahun sebanyak 19 responden mengalami amenorea sedangkan akseptor yang menggunakan KB sunik 3 bulan dari kurang 1 tahun sebanyak 11 responden dan semua tidak mengalami amenorea (spooting masuk kedalam katagori tidak mengalami amenorea).

Waktu penggunaan metode kontrasepsi tergantung dari lamanya pemakaian KB suntik 3 bulan tetapi ada beberapa individu yang $\geq 1$ tahun menggunakan KB suntik 3 bulan tidak mengalami gangguan menstruasi karena reaksi masing-masing individu berbeda terhadap pemakaian KB suntik 3 bulan.

\section{Gangguan Menstruasi Pada Akseptor KB}

Menurut teori Prawihadjo, (2008) Gangguan menstruasi di sebabkan ketidak seimbangan FSH atau LH sehingga kadar estrogen dan progesteron tidak normal. Biasa gangguan menstruasi yang sering terjadi adalah siklus menstruasi tidak teratur atau jarang dan perdarahan yang lama atau upnormal, termasuk akibat sampingan yang di timbulkan nya, seperti nyeri perut, pusing, mual atau muntah.

Menurut teori Hartanto, (2010) kontrasepsi suntik mempunyai permasalahan atau efek samping. Pada pemakian KB suntik mengalami beberapa permasalahan utama yaitu gangguan pola haid. Gangguan haid yang terjadi tergantung pada lama pemakian. Gangguang haid yang terjadi seperti perdarahan bercak, perdarahan ireguler, amenorea dan perubahan dalam frekuensi, lama dan jumlah darah yang hilang.

Penelitian ini sejalan dengan penelitian yang dilakukan oleh Dano (2013) dapat di simpulkan bahwa 81 responden yang menggunakan kontrasepsi suntik 3 bulan mengalami gangguan menstruasi. Menurut Baziad (2002) dikutip dari Nurmasadah (2010) jumlah darah haid yang keluar selama penggunaan KB suntik DMPA akan berkurang hingga 50-70 \% terutama penggunaan awal. Setelah menggunakan jangka lama, jumlah darah yang keluar juga makin sedikit dan bahkan sampai terjadi amenorea, amenorea disebabkan penambahan progesteron.

Gangguan menstruasi pada akseptor KB suntik 3 bulan di akibatkan karena ketidak seimbangan FSH atau LH sehingga kadar estrogen dan progesteron sehingga endometrium mengalami perubahan histology dan kontrsepsi suntik 3 bulan mengakibatkan dinding endometrium yang semakin menipis Lendir servik menjadi kental dan sedkit, sehingga merupakan barier terhadap spermatozoa. hingga menimbulkan ganguan menstruasi. Namun tidak semua wanita yang menggunakan KB suntik 3 bulan akan mengalami gangguan menstruasi dan ada yang mengalami efek samping dan tidak mengalami efek samping.

\section{Gangguan Menstruasi Pada Akseptor KB Berdasarkan Jenis Gangguannya}

Menurut Ekawati (2010) sama dengan penelitian ini yaitu efek Samping Pemakian Kontrasepsi Suntik 3 Bulan yaitu gangguan siklus haid atau menstruasi seperti tidak mengalami haid (amenorea), perdarahan 
berupa tetesan atau bercak bercak (spooting), perdarahan di luar siklus haid (mentroragia atau breakhtrought bleeding), perdarahan haid yang lebih lama atau lebih banyak dari biasa nya. Hal ini karena kontrasepsi menimbulkan perubahan histologi pada endometrium, dari gambaran campuran ( fase proliferasi dan sekresi) sampai atropi dari endometrium.

Dari hasil penelitian yang dilakukan oleh peneliti tentang Lama Pemakian Alat Kontrasepsi KB Suntik 3 Bulan Dengan Gangguan Menstruasi Pada Akseptor KB dari data yang di dapat bahwa dari 34 responden, yang mengalami Haid seperti Amenorea (tidak terjadi perdarahan) Sebanyak 22 orang $(66,7 \%)$, spooting (Bercak-bercak) sebanyak 1orang $(2,9 \%)$, dan menoragia (perdarahan banyak) sebanyak 1 orang $(2,9 \%)$.

Gangguan menstruasi pada akseptor KB suntik 3 bulan dengan jenis gangguannya berdasarkan hasil penelitian yang dilakukan menunjukan bahwa yang mengalami gangguan menstruasi setelah pemakaian $\mathrm{KB}$ suntik 3 bulan yaitu: Amenorea, Spooting, Menoragia. Amenorea di sebabkan karna adanya penambahan progesteron sehingga menyebabkan tidak terjadinya perdarahan akibat dari pemakain KB suntik 3 bulan, Spooting (bercak-bercak) di sebabkan karna endometrium mengalami perubahan pada pola haid tergantung pada lama pemakain, pendarahan inter menstruasi dan perdarahan bercak berkurang dengan berjalannya waktu pada pemakaian KB suntik 3 bulan, Menoraghia (perdarahan banyak) di sebabkan karna respon tubuh dan ketidak seimbangan hormon dalam penggunaan KB suntik 3 bulan yang merangsang hormon progesteron untuk menghasilkan corpus luteum lebih banyak sehingga dapat menjadi resiko terjadinya menoraghia.

Pada gangguan menstruasi faktorfaktor di atas bisa terjadi, dan menstruasi akan kembali normal dalam biasanya setelah 1 hingga 3 bulan atau bahkan lebih lama beberapa tahun setelah suntikan di hentikan dan ini tergantung dari masing-masing individu.

\section{Hubungan Lama Pemakaian Alat}

\section{Kontasepsi KB Suntik 3 Bulan Dengan} Gangguan Mestruasi Pada Akseptor KB

Kontrasepsi suntik adalah cara untuk mencegah terjadinya kehamilan dengan melalui suntikan hormonal. Kontrasepsi hormonal jenis KB suntikan di indonesia semakin banyak dipakai karena kerjanya yang efektif, pemakain yang praktis, harga relatif murah dan aman. Sebelum di suntik, kesehatan ibu harus diperiksa dulu untuk memastikan kecocokannya. Suntik di berikan saat ibu dalam keadaan tidak hamil.

Umumnya pemakaian suntikan KB mempunyai persyaratan sama dengan pemakain pil, begitu pula orang yang tidak boleh memakai suntikan $\mathrm{KB}$, termasuk menggunakan cara $\mathrm{KB}$ hormonal selama maksimal 5 tahun (Yosef, 2009). Lamanya penggunaan kontrasepsi suntik pada akseptor $\mathrm{KB}$ suntik rata-rata memiliki keberhasilan di atas 99\%. Keuntungan menggunakan KB suntik adalah praktis, efektif dan aman. Tidak membatasi usia dan obat KB suntik 3 bulan sekalipun tidak mempengaruhi 
asi dan cocok untuk ibu yang menyusui (Irianto, 2010).

Umumnya pemakaian KB suntik 3 bulan mempunyai persyaratan yang sama dengan pil, kontinuitas kontrasepsi suntik cukup tinggi, 5075\% setelah 1 tahun, penggunaan cara $\mathrm{KB}$ hormonal maksimal selama 5 tahun, semakin lama masa pemaiakan KB suntik akan menimbulkan beberapa dampak baik mual muntah, perdarahan libido, pengeroposan tulang dan lainya (Harnawati, 2008).

Gangguan Menstruasi atau kelainan haid biasanya terjadi karena ketidak seimbangan hormon-hormon yang mengatur haid, namun dapat juga di sebabkan oleh kondisi medis lainnya. Banyaknya perdarahan ditentukan oleh lebarnya pembulu darah, banyak nya pembuluh darah yang terbuka, dan tekanan intravaskuler. Lamanya perdarahan ditentukan oleh daya penyembuhan luka atau daya regenerasi berkurang pada infeksi, mioma, polip dan pada kasinoma (Dewi, 2012)

Hal ini sesuai dengan teori yang ditemukan oleh Saiffudin (2006), Penggunaan suntik progestin sering menimbulakan gangguan menstruasi seperti siklus haid yang memendek atau memanjang, perdarahan yang banyak atau sedikit, perdarahan yang tidak teratur atau perdarahan yang bercak (spooting), dan tidak haid sama sekali.

Dari penelitian diatas yang menyatakan bahwa ada Hubungan Lama Pemakian Alat Kontrasepsi KB Suntik 3 Bulan Dengan Gangguan Menstruasi Pada Akseptor KB Di Puskesmas Siantan Hilir Pada Tahun 2019. Dari hasil penelitian ini di dapatkan bahwa dari 34 responden yang ada, 24 responden $(70,5 \%)$ yang menggunakan KB suntik 3 bulan $\leq$

1 tahun di antaranya mengalami gangguan menstruasi dan 10 orang responden $(29,5 \%)$ lainnya tidak mengalami gangguan menstruasi. Dan dari hasil penelitian ini di simpulkan bahwa ada hubungan lama pemakaian alat kontrasepsi $\mathrm{Kb}$ suntik 3 bulan dengan gangguan menstruasi pada akseptor KB karena $\mathrm{X}^{2}$ hitung $(8,502)<X^{2}$ tabel $(3,841)$ maka Ha di terima dan Ho di tolak. Berdasarkan penelitian yang dilakukan oleh peneliti ada Hubungan antara lama pemakian $\mathrm{KB}$ suntik 3 bulan dengan gangguan menstruasi pada akseptor KB suntik 3 bulan. Jadi sebaiknya pada akseptor KB suntik 3 bulan jika merasa mengalami gangguan menstruasi bisa memodifikasi $\mathrm{KB}$ atau merubah metode kontrasepsi yang tidak mengganggu siklus menstruasi.

\section{Kesimpulan}

Ada Hubungan Lama Pemakian Alat Kontrasepsi KB Suntik 3 Bulan Dengan Gangguan Menstruasi Pada Akseptor KB Di Puskesmas Siantan Hilir Pada Tahun 2019. Bagi Puskesmas Siantan Hilir Pihak Puskesmas tetap dilakukan informasi pada pengguna $\mathrm{KB}$ suntik 3 bulan terutama tentang efek samping pemakaian KB suntik 3 bulan, serta menjelaskan pada klien bahwa ada hubungan antara lama pemakaian KB suntik 3 bulan dengan gangguan menstruasi, dan menganjurkan klien jika merasa ada gangguan terhadap pemakaian KB suntik 3 bulan untuk mengganti metode kontrasepsi lainnya. 


\section{Daftar Pustaka}

Arikunto Suharsimi. 2010. Prosedur Penelitian. Rineka Cipta: Jakarta

Anisa Dkk,2014 Hubungan Lama Penggunaan Kontrasepsi Suntik Dmpa Dengan Siklus Haid Di Kb Kartika Bandar Lampung. Naskah publikasi Yogyakarta. Stikes Aisiyah Yogyakarta. http.opac.say.ac.id Diakses: 22 Maret 2019 16.15 WIB

Dewi Syntia. 2012. Biologi Reproduksi. Pustaka Rihama.Yogyakarta

Dinas Kesehatan RI.2014 Riset Kesehatan Dasar. Jakarta: Badan Penelitian dan pengembangan

Kemenkes RI.www.depkes.go.id.lak kemenkes, 2014. Diakses : 15 Maret, 201919.30 WIB

Dinas Kesehatan Kalimantan Barat, 2017. Profil Kesehatan Kalimantan Barat.http://dinkeskalbarprov.go.id. Diakses: 15 Maret,2019 19.40 WIB

Ekawati, Desi 2010. Pengaruh KB Suntik DMPA Terhadap Peningkatan Berat Badan Di BPS Siti Syamsiyah Wonokarto Wonogiri. Jurnal. Surakarta: FK Universitas Sebelas Maret Surakarta. Http://digilib. Uns.ac.id 27 Maret 2019 17.00 WIB

Hidayatun Nur,2017 Hubungan Lama Penggunaan KB Suntik Progestin Dengan Kejadian Gangguan Siklus Menstruasi Pada Akseptor KB Suntik Progestin di BPM Widyawati Bantul. Naskah Publik.Yogyakarta. http://opac.say.ac.id, di akses pada: 15 maret 2019, 20.00 WIB

Hartanto Hanafi. 2010. Keluarga Berencana dan Kontrasepsi. Pustaka Sinar Harapan: Jakarta

Harnawati.2008. Lama Pemakaian KB Suntik 3 Bulan.http:// Harnawati. wordpress.com di akses: 27 Maret,2019, 18.30 WIB
Hestiantoro.2009. Masalah Gangguan Haid dan Infertilitas. FKUI: Jakarta

Imron Riyanti. 2016. Biologi Dasar Manusia. $\mathrm{Cv}$. Trans Info Media: Jakarta

Irianto Koes. 2010. Kesehatan Reproduksi. Cv. Media Sarana: Bandung

\section{Pelayanan Keluarga}

Berencana. Cv.Alfabeta: Bandung

K.A Anisa. 2015 Hubungan Lama Penggunaan Kontrasepsi Suntik DMPA Dengan Siklus Haid. Jurnal Keperawatan Tanjungkarang.

file:///C:/Users/asus/Downloads/JURNA

L\%20KU/contoh\%20kti\%201.pdf, di akses pada: 15 maret 2019,20.00 WIB

Marmi.2015. Kesehatan Reproduksi. Pustaka Pelajar: Yogyakarta

.2016. Buku Ajar Pelayanan KB. Pustaka Pelajar: Yogyakarta

Manuaba, Ida Bagus Gde.2010. Ilmu Kebidanan, Penyakit Kandungan dan Keluarga Berencana untuk Pendidikan Bidan.Jakarta: EGC

Notoadmodjo,2011. Metodologi Penelitian Ilmu Keperawatan pedoman Skripsi, Tesis dan instrument penelitian Keperawatan/Nursalam. Jakarta: Selamba Medika

Nugroho Taufan, Indra Bobby. 2014. Masalah Kesehatan Reproduksi Wanita. Nuha Medika: Yogyakarta

Nurhidayatun, 2017. Hubungan Lama Penggunaan KB Suntik Progestin Dengan Kejadian Gangguan Siklus Menstruasi Pada Akseptor Kb Suntik Progestin Di BPM Widyati Bantul. Yogyakarta. http:acd.say.ac.id Diakses :22 maret 201918.40 WIB

Prawihardjo.S.2008. Ilmu Kandungan. YBP. SP: Jakarta

Pinem. 2009. Kesehatan Reproduksi dan Kontrasepsi. Trans Info Media: Jakarta 